\title{
MICRO-RNAS DIFFERENTIALLY EXPRESSED IN COMPARATIVE ANALYSIS OF SPERM SAMPLES WITH HIGH AND LOW EFFICIENCY IN THE IN VITRO PRODUCTION OF BOVINE (Bos Taurus) EMBRYOS
}

\author{
MICRO-RNAS DIFERENCIALMENTE EXPRESSOS EM ANÁLISE COMPARATIVA \\ DE AMOSTRAS DE ESPERMATOZOIDES COM ALTA E BAIXA EFICIÊNCIA NA \\ PRODUÇÃO IN VITRO DE EMBRIÕES BOVINOS (Bos Taurus)
}

\begin{abstract}
Ricardo Tomaz da SILVA ${ }^{1}$; Matheus de Souza GOMES ${ }^{2}$; Patrícia Tiemi FUJIMURA ${ }^{3}$; Carlos UEIRA-VIEIRA ${ }^{3}$; Laurence Rodrigues do AMARAL ${ }^{4}$ Marcelo Emílio BELETTI ${ }^{5}$

1. Graduate Program in Veterinary Science, Faculdade de Medicina Veterinária, Universidade Federal de Uberlândia, Uberlândia, Minas Gerais, Brazil; 2. Laboratory of Bioinformatics and Molecular Analysis, Instituto de Biotecnologia, Universidade Federal de Uberlândia, Patos de Minas, Minas Gerais, Brazil; 3. Laboratory of Genetic, Instituto de Biotecnologia, Universidade Federal de Uberlândia, Uberlândia, Minas Gerais, Brazil; 4. Faculdade de Computação, Universidade Federal de Uberlândia, Uberlândia, Minas Gerais, Brazil; 5. Loboratory of Biology of Reproduction, Instituto de Ciências Biomédica, Universidade Federal de Uberlândia, Uberlândia, Minas Gerais, Brazil.
\end{abstract}

\begin{abstract}
Infertility or subfertility in bovine males may be related to spermatic microRNAs (miRNAs), whose function seems to be associated with the regulation of gene expression, degradation or storage of messenger RNAs (mRNAs) for later translation into early embryonic development. Thus, the purpose of this study was to identify differentially expressed miRNAs in semen samples from bulls (Bos taurus) with low and high efficiency in the in vitro embryo production (IVEP) and to evaluate if they can be used as markers of semen efficiency for IVEPs. In order to identify miRNA markers of semen efficiency in the in vitro embryo production, eight semen samples from each animal, one bull with high and two bulls with low efficiency in IVEPs were used to perform the RNAseq technique for miRNAs. Initially the samples were washed with PBS to remove the extender semen and subsequently were submitted to RNA extraction protocols performed according to procedures described by mirVana ${ }^{\mathrm{TM}}$ miRNA Isolation Kit. Then, the amplification of the miRNAs was carried out, not to mention the preparation of the library (Ion Total RNA-Seq Kit v2), the PCR emulsion reaction, enrichment, as well as the injection of the sample on the chip by the Ion Chef equipment. The sequencing was done on Ion Proton equipment. The comparison between the samples was established using two methodologies for searching for targets to increase the robustness of the analytical procedure: the miRanda program using as cutoff minimum free energy of the hybridization $-20 \mathrm{kcal} / \mathrm{Mol}, 100 \%$ of identity between nucleotides 2 and 8 of the miRNA, and the RNAhybrid program, using as cutoff minimum free energy of hybridization $-20 \mathrm{kcal} / \mathrm{mol}$. In sum, 1306 miRNAs were identified in the samples. The bta-miR380-5p, bta-miR-155, bta-miR-30c and bta-miR-34a genes were identified by the Bioinformatics as being strongly differentially expressed between the groups, indicating that these genes may present themselves as possible efficiency markers. However, it has become clear that there is no single miRNA that marks different types and causes of fertility problems.
\end{abstract}

KEYWORDS: RNAseq. Fertility. Gene regulation.

\section{INTRODUCTION}

Animal reproduction has benefited from research in the area of molecular biology, presenting the possibility of improving fertility indexes based on greater and more specific knowledge of the mechanism of action, identification and characterization of RNAs. Some of the doubts about the physiological infertility mechanisms in males could be clarified by the identification and recognition of the microRNAs (miRNAs) functions (KHAZAIE; NASR-ESFAHANI, 2014).
Described as nucleotide groups whose length ranges from 18 to 23, miRNAs are found not only in animal or plant cells but also in viruses (PFEFFER et al., 2004; WASHIETL et al., 2012), and act on the mRNAs in the regulation of gene expression by translational repression, degradation or storage for later translation (COSTA; PACHECO, 2012).

Small non-coding RNAs, miRNAs participate in the regulation of various physiological processes, apparently acting after fertilization (NISHIMURA; DODE, 2014) and their discovery allowed a new insight into the mechanisms of gene 
regulation (WASHIETL et al., 2012). According to Ge et al. (2015), miRNA populations are critical for the development of germ cells in males, acting on postnatal spermatogenesis, and on spermatocytes and spermatids, showing their role in fertility.

Studies point out that miRNAs are tissuespecific and, as such, are involved in differentiation processes in specific cells (DIAS CORREIA; DIAS CORREIA, 2007). Studies such as those by Fagerlind et al. (2015) have been emphatic in stating that bull sperm are rich in active miRNAs and that specific sperm miRNAs may be linked to fertility.

The determination of miRNA profiles has become relevant for the understanding of the regulation mechanisms of the different biological processes, including fertility in males, and that bulls with low fertility present larger populations of miRNAs when compared to those of high fertility (RAUBER, 2013). The profiles of certain miRNAs may make them possible fertility markers (MILLER; OSTERMEIER， 2006; AL-GAZI; CARROLL, 2015).

The miRNAs are assigned a strict posttranscriptional and post-translational regulatory profile in several biological processes, acting in a significant way on reproductive processes such as embryogenesis, oogenesis and spermatogenesis (GHORBIAN, 2012). Thus, this study aimed to identify differentially expressed miRNAs in semen samples from bulls (Bos taurus) with low and high efficiency in the in vitro embryo production (IVEP) and to evaluate if they can be used as markers of semen efficiency for IVEPs.

\section{MATERIAL AND METHODS}

Eight samples with $0.5 \mathrm{ml}$ of cryopreserved semen from each of the three crossbred (Girolando race) were used, being one bull (T0) with high indexes when used in IVEPs and other two bulls with low IVBPs indexes (T1 and T2). To evaluate the efficiency of the samples, 50 PIVEs were performed using approximately 3,000 viable oocytes (on average 20 oocytes per bull per IVEP). Oocytes collected from slaughterhouse ovaries by follicular aspiration were subjected to maturation (IVM), fertilization (IVF), and in vitro culture (IVC) according Lucio et al. (2016). The cumulus oocytes complexes (COCs) were aspirated from follicles between 3 and $8 \mathrm{~mm}$ in diameter. Then, COCs with a homogeneous cytoplasm and several cell layers were selected and subjected to IVM in modified TCM 199 supplemented with $10 \%$ fetal calf serum $(\mathrm{v} / \mathrm{v})$. On average, 20 selected oocytes matured in drops $(100 \mathrm{~mL})$ over $22-24$ hours at $38.5{ }^{\circ} \mathrm{C}$ in $5 \%$
SILVA, R. T. et al.

$\mathrm{CO}_{2}$ in the air. After IVM, the COCs were rinsed in Tyrode's albumin lactate pyruvate (TALP) medium and fertilized into drops of TALP supplemented with penicillamine, hypotaurine, epinephrine, heparin, and bovine serum albumin. The semen samples were collected from three clinical healthy bulls by artificial vagina and frozen with tris-egg yolk-glycerol extender. For fertilization, frozen semen was thawed, and sperm cells were obtained after treatment with a Percoll (45 and 90\% gradient). The final sperm concentration added per fertilization drop was $1 \times 10^{6}$ motile sperm $/ \mathrm{mL}$. The sperm cells were coincubated with oocytes (19-22 hours) under the same conditions described for maturation. After IVF, presumptive zygotes were denuded by repeated pipetting and washing, and then transferred to a culture dish (4-well) with modified synthetic oviduct fluid containing 5\% fetal calf serum $(\mathrm{v} / \mathrm{v})$. The IVC was performed in a humidified atmosphere at $38.5{ }^{\circ} \mathrm{C}$ in $5 \% \mathrm{CO}_{2}$ in the air and the embryos were checked at Day 7 after fertilization for blastocyst formation. The mean rate of morphologically normal blastocysts (JAKOBSEN et al,, 2006) on day seven after fertilization from the bull T0 was $47 \%$, that from the bull T1 was $13.40 \%$ and that from the bull T2 was $16.36 \%$.

The non-sexed sperm straws of each bull were thawed in a water bath set to $36{ }^{\circ} \mathrm{C}$ for 30 seconds. The contents of two straws $\left(80 \times 10^{6}\right.$ spermatozoa) were placed in a $2 \mathrm{~mL}$ conical bottom microtube, which was filled with PBS, homogenized and centrifuged at $9,500 \times \mathrm{g}$ for 3 minutes at $4{ }^{\circ} \mathrm{C}$. The supernatant, containing cryoprotectants and egg yolk, was carefully removed using a micropipette. For three more times the pellet was resuspended in 1 $\mathrm{ml}$ PBS, centrifuged and the supernatant removed. Following this final step, the sperm pellet was stored at $-80{ }^{\circ} \mathrm{C}$. These samples from each bull were submitted to RNA extraction protocols performed according to procedures described by mirVana ${ }^{\mathrm{TM}}$ miRNA Isolation Kit (AM1560) (Life Technologies Corporation). Then, the amplification of the miRNAs was carried out, not to mention the preparation of the library (Ion Total RNA-Seq Kit v2), the PCR emulsion reaction, enrichment, as well as the injection of the sample on the chip by the Ion Chef equipment. The sequencing was done on Ion Proton equipment (Ion Proton TM System, Thermo Fisher Scientific Inc.).

The microRNA library (Ion Total RNA-Seq v2 kit) was prepared according to the protocol where the hybridization was performed with hybridization solution $(3 \mu \mathrm{L})$, Ion Adapter Mix V2 $(2 \mu \mathrm{L})$ and MicroRNA-3 $\mu \mathrm{L}$ (1-100ng of miRNA), 
performed in two thermocycles $\left(65^{\circ} \mathrm{C}-10 \mathrm{~min}\right.$ and $\left.16^{\circ} \mathrm{C}-5 \mathrm{~min}\right)$.

To perform the binding, the reaction was carried out at $16^{\circ} \mathrm{C}$ for 4 hours using binding buffer $(10 \mu \mathrm{L})$ and Mix binding enzyme $(2 \mu \mathrm{L})$, being added Reverse Transcriptase (H2O nuclease free - $2 \mathrm{uL}$, RT buffer $10 \mathrm{X}-4 \mu \mathrm{L}, 2.5 \mathrm{mM}$ dNTP Mix $-2 \mu \mathrm{L}$ and Ion RT Primer V2 $-16 \mu \mathrm{L}$ ), and the sample was incubated at $70^{\circ} \mathrm{C}$ for $10 \mathrm{~min}$ and then placed on ice, being added $4 \mu \mathrm{L}$ of SuperScript III Enzyme to the reaction, incubated at $42^{\circ} \mathrm{C}$ for $30 \mathrm{~min}$.

The cDNA purification was performed with the Magnetic Bead Cleanup Module, for DNA amplification and Barcodes insertion. From each cDNA, $6 \mu \mathrm{L}$ were transferred to the new tube and Taq platinum PCR SuperMix High Fidelity $(45 \mu \mathrm{l})$ and Ion Xpress RNA 3 Barcode primer $(1 \mu \mathrm{L})$ (barcode 1-16) were added. In a thermocycler (BioRad, T100 Thermal Cycler), the 2 cycles $\left(94^{\circ} \mathrm{C}\right.$ $2 \mathrm{~min})$ and 14 cycles $\left(94^{\circ} \mathrm{C}-30 \mathrm{~s}, 50^{\circ} \mathrm{C}-30 \mathrm{~s}, 68^{\circ} \mathrm{C}\right.$ $30 \mathrm{~s}, 94^{\circ} \mathrm{C}-30 \mathrm{~s}, 62^{\circ} \mathrm{C}-30 \mathrm{~s}, 68^{\circ} \mathrm{C}-30 \mathrm{~s}$ and $68^{\circ} \mathrm{C}-$ $5 \mathrm{~min}$ ) were performed.

The reaction was purified with Magnetic Bead Cleanup Module, emulsion PCR and the enrichment reaction were carried out on the Chef Ion using the PI IC 200 Ion kit and the PI Ion chip for 16 hours, whereas sequencing was carried out on the Ion Proton using the Ion PI Sequencing 200.
The isolated miRNAs from each evaluated bull were sent to the bioinformatics analysis, so that those differentially expressed were identified in the animals evaluated. The comparison between the samples was established using two methodologies for searching for targets to increase the robustness of the analytical procedure: the miRanda program using as cutoff minimum free energy of the hybridization $-20 \mathrm{kcal} / \mathrm{Mol}, 100 \%$ of identity between nucleotides 2 and 8 of the miRNA, and the RNAhybrid program, using as cutoff minimum free energy of hybridization $-20 \mathrm{kcal} / \mathrm{mol}$. Both procedures were implemented in an offline Linux platform to perform the experiment in a highthroughput way. A 3' Bos taurus UTR database was created using Biomart-Ensembl to perform target search for miRNAs identified as differentially expressed.

\section{RESULTS}

The miRNAs bta-miR-380-5p, bta-miR-155 and bta-miR-34a, among 1306 identified, were strongly differentially expressed when comparing $\mathrm{T} 1 / \mathrm{T} 2$ and T0 samples. There was greater expression of the miRNAs bta-miR-380-5p and btamiR-155 in the T1 samples and lower expression of bta-miR-34a in the T2 sample when compared to the sample $\mathrm{T} 0$ according to data presented in table 1 .

Table 1. Differentially expressed miRNAs in semen samples from bulls with low (T1 and T2) and high (T0) efficiency in the in vitro embryo production.

\begin{tabular}{|c|c|c|c|c|c|}
\hline \multirow{2}{*}{\multicolumn{2}{|c|}{$\begin{array}{c}\text { Identification } \\
\text { miR Base } \\
\text { Mature Sequence }\end{array}$}} & \multicolumn{2}{|c|}{ T1 sample } & \multicolumn{2}{|c|}{ T0 sample } \\
\hline & & Seq sample & Seq (normal) & $\begin{array}{c}\text { Seq } \\
\text { sample }\end{array}$ & Seq (normal) \\
\hline $\operatorname{miR}-380-5 p$ & ugguugaccauagaacaugcgc & 11472.0 & 6694.0 & 1.0 & 0.7 \\
\hline \multirow[t]{3}{*}{$\operatorname{miR}-155$} & uuaaugcuaaucgugauaggggu & 5478.0 & 3196.4 & 3.0 & 2.2 \\
\hline & & \multicolumn{2}{|c|}{ T2 sample } & \multicolumn{2}{|c|}{ T0 sample } \\
\hline & & Seq sample & Seq (normal) & $\begin{array}{c}\text { Seq } \\
\text { sample }\end{array}$ & Seq (normal) \\
\hline $\operatorname{miR}-34 \mathrm{a}$ & uggcagugucuuagcugguugu & 217.0 & 126.9 & 3801.0 & 2800.6 \\
\hline
\end{tabular}

After using the RNAhybrid and miRanda softwares, there were 389 targets found in both programs, of which 17 were for bta-miR-380-5p, 15 for bta-miR-155 and 357 for bta-miR-34a. Those found in only one of the programs were not taken into account. Myomesin 3 was identified as a target with a higher level of significance for bta-miR-380$5 \mathrm{p}$ (e-value $=0.000766)$, de-etiolated homolog 1 (Arabidopsis) for bta-miR-155 (e value $=0.042995$ ) and phosphofurin acidic cluster sorting protein 1 for bta-miR-34a $($ e-value $=0.000115)($ table 2$)$. 
Table 2. Targets of differentially expressed miRNAs, biological functions and actions

\begin{tabular}{cccccc}
\hline miRNA & e-value & Target & Description & $\begin{array}{c}\text { Molecular } \\
\text { Function }\end{array}$ & Biological Process \\
miR-380-5p & 0.000766 & $\begin{array}{c}\text { Uncharacterized } \\
\text { Protein }\end{array}$ & myomesin 3 & unidentified & Not described \\
miR-155 & 0.042995 & $\begin{array}{c}\text { Uncharacterized } \\
\text { Protein }\end{array}$ & $\begin{array}{c}\text { de-etiolated } \\
\text { homolog 1 } \\
\text { (Arabidopsis } \\
\text { ) }\end{array}$ & unidentified \\
miR-34a & 0.000115 & $\begin{array}{c}\text { Uncharacterized } \\
\text { Protein }\end{array}$ & $\begin{array}{c}\text { phosphofuri } \\
\text { n acidic } \\
\text { cluster } \\
\text { sorting } \\
\text { protein 1 }\end{array}$ & $\begin{array}{c}\text { Connecting ion } \\
\text { channel }\end{array}$ & $\begin{array}{c}\text { Target Protein for the } \\
\text { Golgi Complex Target } \\
\text { Protein for the Plasma } \\
\text { Membrane }\end{array}$ \\
\hline
\end{tabular}

\section{DISCUSSION}

Expression of miRNAs exhibits variations between animals with high and low efficiency in IVEP, with miRNAs miR-380-5p and miR-155 being more expressed in the $\mathrm{T} 1$ sample whereas miR-34a was presented with lower degree of expression in the $\mathrm{T} 2$ sample, when compared to the high efficiency sample (table 1). Govindaraju et al. (2012) also found abundance of miRNAs in bulls and only seven of these miRNAs were differently expressed in fertile and subfertile bulls. However, none of these seven miRNAs were identified in the present study. However, none of these seven miRNAs were identified in the present study. The observed result raises the hypothesis that there are differences in the miRNA content between individuals with high and low efficiency in IVF, and even among those of low efficiency, since it was observed that the miRNAs identified were not the same in samples $\mathrm{T} 1$ and $\mathrm{T} 2$. This fact can be attributed to different causes of subfertility. Despite the same race and gender, other variables may have led to the observed difference.

Fagerlind et al. (2015) used a modified TRIzol protocol for total RNA isolation and RTqPCR to study the gene expression of 178 miRNAs in spermatozoa from Holstein bulls with moderate to high fertility, including miR-34a and miR-155. Seven genes were differentially expressed, but miR34a and miR-155 were not among them. However, miR-34c, from the same miR-34a family, was differentially expressed. According to these authors, members of the miR-34 family are differentially expressed during implantation in the uterus and in spermatozoa. This fact would indicate that an aberrant expression in spermatozoa can have implications, at least during the early stages of pregnancy. In the present study, the miR-34a was found in a smaller quantity in a low-efficiency sample in IVEPs.

Capra et al. (2017) identified 83 miRNAs differentially expressed in the high- and low-motile sperm fractions separated by Precoll from four different bulls. Among these miRNAs were not the three miRNAs identified in the present work. However, two miRNAs from the miR-34 family (miR-34b and miR-34c) had high expression in the fraction with high motility. Differently, we found lower expression of miR-34a in a low-efficiency sample in IVEPs.

Swarbrick et al. (2017) and Cimino-Reale et al. (2017) report that miR-380-5p has been found in studies related to tumor and embryonic cells, which store among themselves the intense multiplication capacity. Its great presence in $\mathrm{T} 1$ can be justified by the fact that the initial embryonic development (blastocyst formation) is also characterized by the intense cellular proliferation and therefore to be affected by this miRNA. Among the probable targets of this miRNA stands out myomesin 3, which has not yet fully clarified biological function.

The miR-155 is related to different tissues, high concentrations of this miRNA may reflect systemic damage and, as a result, affect fertility. They are also related to subfertility in males and with Follicle Stimulating Hormone (FSH) in a mechanism still unknown (TSATSANIS et al., 2015). Faraoni et al. (2009) and Elton et al (2013) cite that miRNA-155 shows a varied expression profile and plays an important part in several biological processes. In inflammatory processes, its action seems to be associated with down-regulate of tissue damage. Its elevated presence may be a marker of testicular tissue damage, which may have occurred during spermatogenesis and could be the 
cause of changes in the spermatozoa leading to lowefficiency in IVEP of the T1. Among the probable targets of this miRNA is de-etiolated homolog 1 (Arabidopsis), which has not yet fully clarified biological function.

According to Zhao, Li e Chen (2010), miRNA 34a was associated with the induction of senescence in parental endothelial cells (EPC), mediators of angiogenesis, via inhibition of Sirt1, a protein that according to Tang (2016) plays a significant role in metabolic regulation and biogenesis of mitochondria, possibly activated under conditions of energy deficiency associated with diseases or injuries. Tscherner et al. (2014) describe the miRNA-34a present in spermatozoa, oocytes and cleaved embryos. Among the probable targets of this miRNA is the phosphofurin acidic cluster sorting protein 1 , which act on ionic channels of binding in the Golgi complex and plasma membrane. Although not yet certain as to its mechanism of action, this current study indicates that its lower expression may be associated with some types of subfertility, since there was an intense decrease in $\mathrm{T} 2$ in its expression.

\section{CONCLUSIONS}

There are differences in the content of miRNAs in semen with high and low efficiency in IVEPs, however, it was not possible to identify a single miRNA that is differentially expressed in all low-efficiency samples, probably due to the low efficiencies of different causes.

The bta-miR-380-5p, bta-miR-155 e btamiR-34a miRNAs differentially expressed in this study require more specific studies for the determination of their action mechanisms, but regardless of this we can consider them as possible markers not only of problems in PIVE, but also markers of the subfertility cause, such as testicular injury, failures in the fertilization process and embryonic development.

\section{ACKNOWLEDGEMENTS}

The authors are grateful to FAPEMIG and $\mathrm{CNPq}$ for financial support.

RESUMO: A infertilidade ou subfertilidade em machos bovinos pode estar relacionada a microRNAs espermáticos (miRNAs), cuja função parece estar associada à regulação da expressão gênica, degradação ou armazenamento de RNAs mensageiros (mRNAs), para posterior tradução no desenvolvimento embrionário inicial. Assim, o objetivo deste estudo foi identificar miRNAs diferencialmente expressos em amostras de sêmen de touros (Bos taurus) com baixa e alta eficiência na produção in vitro de embriões (PIVE) e avaliar se eles podem ser utilizados como marcadores de eficiência do sêmen em PIVEs. Para identificar miRNA marcadores da eficiência de sêmen em PIVE, oito amostras de sêmen de cada animal, sendo um touro com alto e dois touros com baixa eficiência, foram utilizados para realizar a técnica de RNAseq para miRNAs. Inicialmente as amostras foram lavadas com PBS para remover o diluente do sêmen e, posteriormente, foram submetidas a protocolos de extração de RNA realizados de acordo com os procedimentos descritos pelo Kit de isolamento de miRNA mirVana TM. Em seguida, foi realizada a amplificação dos miRNAs, a preparação da biblioteca (Ion RNA-Seq Kit v2), a reação de emulsão de PCR, enriquecimento e a injeção das amostras no chip apropriado utilizando o equipamento Ion. Chef. O sequenciamento foi realizado no equipamento Ion Proton. A comparação entre as amostras foi estabelecida utilizando duas metodologias de busca de alvos para aumentar a robustez do procedimento analítico: o programa miRanda utilizando como valor de corte a energia mínima livre de hibridização $-20 \mathrm{kcal} / \mathrm{Mol}$ e $100 \%$ de identidade entre os nucleotídeos 2 e 8 do miRNA, e o programa RNAhybrid, utilizando como valor de corte a energia mínima livre de hibridização $-20 \mathrm{kcal} / \mathrm{mol}$. Em suma, 1306 miRNAs foram identificados nas amostras. Os genes bta-miR-380-5p, bta-miR-155, bta-miR30c e bta-miR-34a foram identificados pela bioinformática como sendo fortemente diferencialmente expressos entre os grupos, indicando que esses genes podem se apresentar como possíveis marcadores de eficiência. No entanto, ficou claro que não existe um único miRNA que marque diferentes tipos e causas de problemas de fertilidade.

PALAVRAS-CHAVE: RNAseq. Fertilidade. Regulação gênica. 


\section{REFERENCES}

AL-GAZI, M. K.; CARROLL, M. Sperm-Specific MicroRNAs - Their Role and Function. Journal of Human Genetics and Clinical Embryology, Herndon, v. 1, n. 1, art. 3, 2015. https://doi.org/10.24966/GGS2485/100003

CAPRA, E.; TURRI, F.; LAZZARI, B.; CREMONESI, P.; GLIOZZI, T. M; FOJADELLI, I.; STELLA, A.; PIZZI, F. Small RNA sequencing of cryopreserved semen from single bull revealed altered miRNAs and piRNAs expression between High- and Low-motile sperm populations. BMC Genomics, London, v. 18, n. 1, art. 14, 2017. https://doi.org/10.1186/s12864-016-3394-7

JAKOBSEN, A. S.; THOMSEN, P. D.; AVERY, B. Few polyploid blastomeres in morphologically superior bovine embryos produced in vitro. Theriogenology, New York, v. 65, n. 4, p. 870-881, 2006.

https://doi.org/10.1016/j.theriogenology.2005.06.014

CIMINO-REALE, G.; GANDELLINI, P.; SANTAMBROGIO, F.; RECAGNI, M.; ZAFFARONI, N.; FOLINI, M. miR-380-5p-mediated repression of TEP1 and TSPYL5 interferes with telomerase activity and favours the emergence of an "ALT-like" phenotype in diffuse malignant peritoneal mesothelioma cells. Journal of hematology and oncology, London, v. 10, art. 140, 2017. https://doi.org/10.1186/s13045-017-0510-3

COSTA, E. B. O.; PACHECO, C. Micro-RNAs: Perspectivas atuais da regulação da expressão gênica em eucariotos. Biosaúde, Londrina, v. 14, n. 2, p. 81-93, 2012.

http://www.uel.br/ccb/patologia/portal/pages/arquivos/Biosaude\%20v\%2014\%202012/BS_14_2_2012_DF_26. pdf

DIAS CORREIA, J. H. R.; DIAS CORREIA, A. A. Funcionalidades dos RNA não codificantes (ncRNA) e pequenos RNA reguladores, nos mamíferos. REDVET. Revista Eletrônica de Veterinaria, Gerona, v. 8, n. 10, p.1695-7504, 2007. http://www.veterinaria.org/revistas/redvet/n101007/100705.pdf

ELTON, T. S; SELEMON, H.; ELTON, S. M.; PARINANDI, N. L. Regulation of the MIR155 host gene in physiological and pathological processes. Gene, Amsterdam, v. 532, n. 1, p. 1-12, 2013. https://doi.org/10.1016/10.1016/j.gene.2012.12.009

FAGERLIND, M.; STALHAMMAR, H.; OLSSON, B.; KLINGA-LEVAN, K. Expression of miRNAs in Bull Spermatozoa Correlates with Fertility Rates. Reproduction in domestic animals, Zuchthygiene, v. 50, n. 4 , 2015. https://doi.org/10.1111/rda.12531

FARAONI, I.; ANTONETTI, F. R.; CARDONE, J.; BONMASSAR, E. miR-155 gene: A typical multifunctional microRNA. Biochimica et biophysica acta, Amsterdam, v. 1792, n. 6, p. 497-505, 2009. https://doi.org/10.1016/j.bbadis.2009.02.013

GHORBIAN, S. Micro-RNAs, next-generation molecular markers in male infertility field. Translational Andrology and Urology, Hong Kong, v. 1, n. 4, p. 245-246, 2012. https://doi.org/10.3978/j.issn.22234683.2012.11.01

GOVINDARAJU, A.; UZUN, A.; ROBERTSON, L.; ATLI, M. O.; KAYA, A.; TOPPER, E.; CRATE, E. A.; PADBURY, J.; PERKINS, A.; MEMILI, E. Dynamics of microRNAs in bull spermatozoa. Reproductive biology and endocrinology, London, v. 10, art. 82, 2012. https://doi.org/10.1186/1477-7827-10-82

GE, S. Q.; ZHAO, Z. H.; CUI, T. Z.; GAO, Z. Q. Small Non-Coding RNAs in Mammalian Male Germ Cells and Their Implications for Male Infertility. Andrology Open Access, Henderson, v.4, art. 150, 2015. http://dx.doi.org/10.4172/2167-0250.1000150

KHAZAIE, Y.; NASR-ESFAHANI, M. H. N. MicroRNA and Male Infertility: A Potential for Diagnosis. International Journal of Fertility and Sterility, Tehran, v. 8, n. 2, p. 113-118, 2014. https://www.ncbi.nlm.nih.gov/pmc/articles/PMC4107683/pdf/Int-J-Fertil-Steril-8-113.pdf 
LUCIO, A. C.; ALVES, B. G.; ALVES, K. A.; MARTINS, M. C.; BRAGA, L. S.; MIGLIO, L.; ALVES, B. G.; SILVA, T. H.; JACOMINI, J. O.; BELETTI, M. E. Selected sperm traits are simultaneously altered after scrotal heat stress and play specific roles in in vitro fertilization and embryonic development. Theriogenology, v.86, n.4, p. 924-933, 2016. https://doi.org/10.1016/j.theriogenology.2016.03.015

MILLER, D.; OSTERMEIER, G. C. Towards a better understanding of RNA carriage by ejaculate spermatozoa. Human reproduction update, Oxford, v.12, n. 6, p. 757-767, 2006. https://doi.org/10.1093/humupd/dml037

NISHIMURA, R. C.; DODE, M. A. N. RNAs de espermatozoide: qual a sua função fisiológica? Revista Brasileira de Reprodução Animal, Belo Horizonte, v. 38, n. 1, p. 32-36, 2014. http://www.cbra.org.br/pages/publicacoes/rbra/v38n1/pag32-36(RB433\%20Nishimura).pdf

PFEFFER, S.; ZAVOLAN, M.; GRASSER, F. A.; CHIEN, M.; RUSSO, J. J,; JU, J.; JOHN. B.; ENRIGHT, A. J.; MARKS, D.; SANDER, C.; TUSCHL, T. Identification of virus encoded microRNAs. Science, New York, v. 304, n. 5671, p. 734-736, 2004. https://doi.org/10.1126/science.1096781

RAUBER, L. P. RNA espermático, uma visão holística. Revista Brasileira de Reprodução Animal, Belo Horizonte, v. 37, n. 4, p. 309-317, 2013. http://www.cbra.org.br/pages/publicacoes/rbra/v37n4/p309$317 \% 20($ RB401).pdf

SWARBRICK, A.; WOODS, S. L.; SHAW, A.; BALAKRISHNAN, A.; PHUA, Y.; NGUYEN, A.; CHANTHERY, Y.; LIM, L.; ASHTON, L. J.; JUDSON, R. L.; HUSKEY, N.; BLELLOCH, R.; HABER, M.; NORRIS, M. D.; LENGYEL, P.; HACKETT, C. S.; PREISS, T.; CHETCUTI, A.; SULLIVAN. C. S.; MARCUSSON. E. G.; WEISS, W.; L'ETOILE, N.; GOGA, A. miR-380-5p represses p53 to control cellular survival and is associated with poor outcome in MYCN amplified neuroblastoma. Nature medicine, New York, v. 16, n. 10, p. 1134-1140, 2010. https://doi.org/10.1038/nm.2227

TANG, B. L. Sirt1 and the Mitochondria. Molecules and cells, Seoul, v. 39, n. 2, p. 87-95, 2016. https://doi.org/10.14348/molcells.2016.2318

TSATSANIS. C.; BOBJER, J.; RASTKHANI, H.; DERMITZAKI, E.; KATRINAKI, M.; MARGIORIS, A. N.; GIWERCMAN, Y. L.; GIWERCMAN, A. Serum miR-155 as a potential biomarker of male fertility. Human reproduction, Oxford, v. 30, n. 4, p. 853-60, 2015. https://doi.org/10.1093/humrep/dev031

TSCHERNER, A.; GILCHRIST, G.; SMITH, N.; BLONDIN, P.; GILLIS, D.; LAMARRE, J. MicroRNA-34 family expression in bovine gametes and preimplantation embryos. Reproductive biology and endocrinology, London, v. 12, art. 85, 2014. https://doi.org/10.1186/1477-7827-12-85

WASHIETL, S.; WILL, S.; HENDRIX, D. A.; GOFF, L. A.; RINN, J. L.; BERGER, B.; KELLIS, M. Computational analysis of noncoding RNAs. Wiley interdisciplinary reviews. RNA, Hoboken, v. 3, n. 6, p. 759-778, 2012. https://doi.org/10.1002/wrna.1134

ZHAO, T.; LI, J.; CHEN, A. F. MicroRNA-34a induces endothelial progenitor cell senescence and impedes its angiogenesis via suppressing silent, information regulator 1. American journal of physiology. Endocrinology and metabolism, Bethesda, v. 299, n. 1, p. E110-E116, 2010. https://doi.org/10.1152/ajpendo.00192.2010 